\title{
The Problematic of Waqf Representatives and The Settlement of Disputes
}

\section{Agung Wicaksono*)}

*) Student Master of Notarial Law, Faculty of Law, Universitas Islam Sultan Agung Semarang, e-mail: agung.muktijaya@gmail.com

\begin{abstract}
The problems in this research are how the problems of Waqf that often occur, the settlement of Waqf land disputes that are asked for back by the heirs, the obstacles faced in resolving the Waqf land disputes that are asked back by the heirs at the Semarang Religious Court. Based on the results of the research, it was found that the Waqf dispute that arose was triggered by, among others, the denial of the Waqf pledge, the desire to withdraw the assets that had been donated. Waqf dispute resolution is pursued in several stages which are carried out stratifically, namely deliberation, mediation, arbitration and the High Religious Court. The obstacle in the process of resolving Waqf disputes is the absence of orderly administration in the practice of Waqf, especially based on authentic evidence such as Waqf pledges and evidence of records at the local KUA District.
\end{abstract}

Keywords: Waqf; Dispute; Sharia.

\section{INTRODUCTION}

In the content of such a large potential of Waqf with management that has not been fully handled professionally and with a productive vision, Waqf also has the potential to generate potential conflicts or disputes in its management. In Indonesia, the issue of donated land belonging to the field of Agrarian Law. In the framework of reforming the National Agrarian Law, ownership of land belonging to the government is given special attention as seen in the Basic Agrarian Act No. 5 of 1960 Chapter IX Article 49 paragraph 3 which provides the following provisions "Representation of property is protected and regulated by a Government Regulation." In addition, Waqf $f^{1}$ is also supported by Government Regulation no. 28 of 1977 regarding the representation of owned land. ${ }^{2}$

The pouring of ownership of land ownership in the UUPA and Government Regulation is the realization of the recognition of elements that rely on religious law. ${ }^{3}$ This is in

\footnotetext{
${ }^{1}$ Alhaddafi, Muhammad Fatih Wahab \& Akhmad Khisni. (2019). The Role Of Notary And Land Deed Official (PPAT) In The Process Of Waqf (Endowments) Deed Making. JURNAL AKTA: Vol 6, No 2, Retrieved from http://jurnal.unissula.ac.id/index.php/akta/article/view/5010

2 Zulfirman. (2003). Wakaf Dalam Perundang-Undangan di Indonesia. Paper for International Seminar on Waqf as a Private Legal Entity, Held in Medan on 6-7 January 2003 p. 5.

${ }^{3}$ Harsono, Boedi. (2003). Sejarah Penyusunan, Isi dan Pelaksanaan UUPA. Volume 1. Jakarta: Jambatan, Revised Edition 2003: p. 220.
} 
accordance with the National Agrarian Law Politics and Pancasila as the principle of state spirituality which covers the entire order of Indonesian law. Thus, in interpreting and implementing applicable agrarian (land) regulations, it must be based on and sourced from Pancasila. ${ }^{4}$ The Waqf Law began to be set forth in separate legislation in 2004 with the issuance of Act No. 41 of 2004 concerning Waqf. The birth of the Law of the Republic of Indonesia No. 41 of 2004 concerning Waqf in addition to being able to provide productive empowerment of Waqf $f^{5}$, namely the management pattern of modern Waqf potential empowerment is expected to be able to become a guideline for resolving cases of Waqf disputes that arise in social reality. If in Government Regulation No.28 of 1977 concerning Ownership of Owned Land, the concept of Waqf is identical to owned land, in the new Waqf Law the concept of Waqf contains a broader dimension. It includes immovable and movable property, and its use is not limited to the construction of places of worship. ${ }^{6}$

In the view of Islam, the assets that have been donated are no longer the property of the Waqf and will not be transferred to the property of the people or entities that are the purpose of the Waqf. Waqf assets have been separated from the ownership rights of the Waqf since the pledge of Waqf was carried out, which later became the property of Allah whose benefit is the right of the recipient of the Waqf. Thus, the Waqf property becomes the mandate of Allah to individuals or legal entities to manage and manage it. The person or body that administers Waqf is called Nadzir or mutawalli. The understanding of Muslims in Indonesia about Waqf, apart from being obtained from religious teachings derived from the Prophet's hadith and fiqh books, is also obtained from customary law or community habits. Because customary law that develops in Indonesia is heavily influenced by Islamic teachings, including regarding Waqf. ${ }^{8}$

\section{METHODS}

The type of this research is a Normative Legal Research. Normative legal Research is a research which uses the law as foundation of norm. This means that this research is based on the library research focusing on reading and analyzing of the primary and secondary materials. In this research, the author describes the case, seek, and process a variety of data from the document study (libraries) to generate a report of research findings.

\footnotetext{
${ }^{4}$ Notonagoro. (1984). Politik Hukum dan Pembangunan Agraria di Indonesia. Jakarta: Bina Aksara, p. 69.

${ }^{5}$ Sukarmi \& Ong Argo Victoria. (2018). Cash Waqf in Sustaining Of Indonesian Society "In Legal \& Economic Perspective". AL-ITQAN: Journal of Islamic Sciences: IIUM Malaysia. Retrieved from: https://journals.iium.edu.my/al-itqan/index.php/al-itqan/article/view/43

6 Ministry of Religion. (2008). New Paradigm of Waqf in Indonesia. Directorate of Waqf Development. Jakarta: Directorate General of Islamic Community Guidance.

7 Farhati, Dewi \& Akhmad Khisni. (2018). Legal Review Of Implementation Endowments Authority Relating To The Under Hand Agreement Made By Waqif (Case Study In Kua Wonosalam, Demak). JURNAL AKTA: Vol. 5, No. 3. Retrieved from http://jurnal.unissula.ac.id/index.php/akta/article/view/3256/2392

8 Mubarok, Jaih. (2008). Wakaf Produktif. Bandung: Dimbiosa Rekatama Media, p. 22.
} 


\section{RESULT AND DISCUSSION}

\subsection{Waqf's Problems That Often Occur}

As social beings, humans always interact with each other. Therefore, for this interaction to run well, it is necessary to regulate both in statutory regulations and other forms of regulation. Basically, all the provisions in the rule must be obeyed by all parties involved in it. Everything must be carried out voluntarily or in good faith, but in reality this is often violated, so that in the end it has the potential to create a dispute between the parties.

Basically every dispute that arises, including a Waqf dispute, has three aspects, namely: ${ }^{9}$

a. Juridical aspects,

b. Sociological aspects,

c. Psychological aspects.

Likewise with Waqf activities that exist in the life of the Muslim community in Indonesia. So far, the potential for disputes in the field of Waqf includes: ${ }^{10}$

a. First relating to Wakif, pledge, Nadzir and witnesses. Usually it concerns whether or not the act of donating is valid.

b. Second, related to the Bayyinah (evidence for the administration of Waqf property), such as the Waqf pledge deed, the replacement deed for the Waqf pledge, proof of ownership of Waqf property or other matters relating to the recording and registration of Waqf.

c. Third, which are related to the management and use of Waqf assets, such as misuse of Waqf assets by Nadzir and others.

The term dispute is usually always associated with conflict. There are people who equate the two terms, but there are also those who distinguish them. For those who differentiate it is stated: ${ }^{11}$

a. Conflict is a situation where the parties are aware or know about the feeling of dissatisfaction.

b. A dispute is a situation where the conflict is stated in public or by involving a third party.

This means that a dispute is a continuation of the conflict, where a conflict will turn into a dispute if it cannot be resolved. Conflict can be defined as "conflict" between the parties to resolve problems that, if not resolved properly, can disrupt the relationship between them. As long as the parties resolve the problem properly, the dispute will not

\footnotetext{
9 Arto, A. Mukti. (2001). Mencari Keadilan, (Kritik dan Solusi Terhadap Praktek Peradilan Perdata). Yogyakarta: Pustaka Prlajar, p. 38.

${ }^{10}$ Hamami, Taufiq. (2003). Perwakaan Tanah (Dalam Politik Hukum Agraria Nasional). Jakarta: PT. Tatanusa, p. 170-171.

${ }^{11}$ Kriekhoff. (1993). Mediasi (Tinjauan dari Segi Antropologı). Jakarta: Yayasan Obor Indonesia, p. 223.
} 
occur. But if the opposite happens; the parties cannot reach an agreement on a solution to the problem; then disputes arise. ${ }^{12}$

\subsection{Settlement of the Land Waqf Dispute Requested by the Inheritance at the Semarang High Religious Court}

These social, economic, political and cultural changes will continue. This needs to be followed by the development of a system to deal with conflicting values from differences of opinion. The system is expected to be able to reduce the possibility of disputes, or to resolve quickly, accurately, and to satisfy the disputing parties in society. ${ }^{13}$

In principle, the disputing parties want a fast, precise, fair and cheap settlement. This has become a general principle in dispute resolution. This is also the case with Waqf disputes. In article 62 of Act No. 41 of 2004 concerning Waqf it is stated that:

1) The settlement of Waqf disputes is taken through deliberation to reach consensus.

2) If the dispute settlement as referred to in paragraph (1) is not successful, the dispute can be resolved through mediation, arbitration or court.

This dispute has been experienced by MWC NU, Genuk District, Semarang City. In $1966 \pm 600 \mathrm{~m} 2$ of land was donated by a Wakif named Ahmad ${ }^{14}$ (deceased) for the benefit of the Islamic organization. In 2012 he was sued by a Wakif heir named Budi ${ }^{15}$ to the Semarang High Religious Court, because there is no evidence to confirm that the land is Waqf land. ${ }^{16}$

According to the author, basically the existence of the status of the Waqf land can be examined based on evidence from records in the local district KUA. However, MWC NU cannot do this because after Wakif has made a Waqf pledge, Wakif and Nadzir do not make a Waqf Pledge Deed in front of PPAIW. The actions taken by Wakif and Nadzir indicate that there is no orderly administration in the practice of Waqf.

\subsection{Constraints Faced in the Settlement of the Wagf Land Dispute Requested by the Heirs at the Semarang High Religious Court}

The mediation process is running smoothly, the parties who are currently litigating have not been able to end the dispute by establishing peace. The Wakif heirs are adamant that the $\pm 600 \mathrm{~m} 2$ land on the Semarang-Purwodadi highway $\pm 5 \mathrm{~km}$ in

12 Usman, Rahmadi. (2003). Pilihan Penyelesaian Sengketa di Luar Pengadilan. Bandung: PT. Citra Aditya Bakti, p. 2.

13 Margono, Suyud. (2000). ADR Alternative Dispute Resolution dan Arbitrase (Proses Pelembagaan dan Aspek Hukum). Jakarta: Ghalia Indonesia, p. 13.

${ }^{14}$ Ahmad's name has been changed according to the request of the Wakif heirs, to protect the good name of the deceased and his family.

${ }^{15}$ Budi's name has been changed according to the request of the Wakif heirs, to protect the good name of the deceased and his family.

${ }_{16}$ Mohammad Ridwan Sulhan (an advocate who accompanied MWC NU), Genuk District, Semarang City in resolving this waqf land dispute), interview, 20 May 2015 at 19.00 WIB. 
Genuk District, Semarang City is not a Waqf land, but the land belonged to his late parents. ${ }^{17}$ Initially, the heirs hoped that the judges of the Semarang High Religious Court would be able to make a decision on the status of the donated land, but in the end this Waqf land dispute could be resolved very simply by means of a mediation mechanism. MWC NU denied the claim and stated that the land had been donated to MWC NU by the parents of the heirs. The existence of the status of the Waqf land can be examined based on evidence from records in the local sub-district KUA. However, MWC NU could not do this because after Wakif had made a wakaf pledge, Wakif and Nadzir did not make a Waqf Pledge Deed in front of PPAIW. The actions taken by Wakif and Nadzir indicate that there is no orderly administration in the practice of Waqf.

From what the authors have described above, the authors conclude that the existence of a formal legal basis regarding the integration of mediation in the judicial system is from the provisions of Article $131 \mathrm{HIR}$ and Article $154 \mathrm{RBg}$. If the mediation that is carried out fails to achieve the word peace, the case examining judge is obliged to continue the case examination in accordance with the provisions of the applicable civil procedural law. However, if the mediation carried out can reach the word peace, it will result in the authorities to notify the judge and request that a stipulation in the form of a peace deed be issued. However, in the opinion of the author, this Waqf dispute will feel much better so that it is resolved in a friendly manner first. So that the parties in dispute or litigation,

\section{CLOSING}

Waqf dispute resolution is pursued in several stages which are carried out stratifically. From the contents of Article 62 paragraph (2), it is known that the first solution recommended by this law is deliberation. This kind of Waqf practice, in the middle of its journey, can lead to problems in the future, for example the issue of the legal validity of the position of Waqf assets which leads to disputes, because there is no evidence to show that the objects in question have been donated.

\section{References}

Journal:

Alhaddafi, Muhammad Fatih Wahab \& Akhmad Khisni. (2019). The Role Of Notary And Land Deed Official (PPAT) In The Process Of Waqf (Endowments) Deed Making. JURNAL AKTA: Vol 6, No 2, Retrieved from http://jurnal.unissula.ac.id/index.php/akta/article/view/5010

Farhati, Dewi \& Akhmad Khisni. (2018). Legal Review Of Implementation Endowments Authority Relating To The Under Hand Agreement Made By Waqif (Case Study In Kua Wonosalam, Demak). JURNAL AKTA: Vol. 5, No. 3. Retrieved from http://jurnal.unissula.ac.id/index.php/akta/article/view/3256/2392

Sukarmi \& Ong Argo Victoria. (2018). Cash Waqf in Sustaining Of Indonesian Society "In Legal \& Economic Perspective". AL-ITQAN: Journal of Islamic Sciences: IIUM Malaysia. Retrieved from: https://journals.iium.edu.my/alitqan/index.php/al-itqan/article/view/43

\footnotetext{
${ }^{17}$ Written proof of Certificate (Proof of MWC NU Waqf Land), op. cit.
} 
Books:

Arto, A. Mukti. (2001). Mencari Keadilan, (Kritik dan Solusi Terhadap Praktek Peradilan Perdata). Yogyakarta: Pustaka Prlajar

Hamami, Taufiq. (2003). Perwakaan Tanah (Dalam Politik Hukum Agraria Nasional). Jakarta: PT. Tatanusa

Harsono, Boedi. (2003). Sejarah Penyusunan, Isi dan Pelaksanaan UUPA. Volume 1. Jakarta: Jambatan, Revised Edition 2003

Kriekhoff. (1993). Mediasi (Tinjauan dari Segi Antropologi). Jakarta: Yayasan Obor Indonesia

Margono, Suyud. (2000). ADR Alternative Dispute Resolution dan Arbitrase (Proses Pelembagaan dan Aspek Hukum). Jakarta: Ghalia Indonesia

Ministry of Religion. (2008). New Paradigm of Waqf in Indonesia. Directorate of Waqf Development. Jakarta: Directorate General of Islamic Community Guidance.

Mubarok, Jaih. (2008). Wakaf Produktif. Bandung: Dimbiosa Rekatama Media

Notonagoro. (1984). Politik Hukum dan Pembangunan Agraria di Indonesia. Jakarta: Bina Aksara

Usman, Rahmadi. (2003). Pilihan Penyelesaian Sengketa di Luar Pengadilan. Bandung: PT. Citra Aditya Bakti

Paper:

Zulfirman. (2003). Wakaf Dalam Perundang-Undangan di Indonesia. Paper for International Seminar on Waqf as a Private Legal Entity, Held in Medan on 6-7 January 2003 